DOI: 10.1590/0103-0582201432214613

\title{
Intake of protein, calcium and sodium in public child day care centers
}

\author{
Ingestão de proteína, cálcio e sódio em creches públicas \\ Ingestión de proteínas, calcio y sodio en guarderías públicas
}

\begin{abstract}
Giovana Longo-Silva ${ }^{1}$, Maysa Helena de A. Toloni ${ }^{2}$, Risia Cristina E. de Menezes ${ }^{1}$, Tatiane Leocádio Temteo ${ }^{1}$, Maria Alice A. Oliveira ${ }^{1}$, Leiko Asakura', Emilia Chagas Costa ${ }^{3}$, José Augusto de A. C. Taddei²
\end{abstract}

\section{ABSTRACT}

Objective: To assess calcium, protein and sodium intake, of children that attend public day-care centers and to compare it with the recommended one.

Methods: Cross-sectional descriptive study in seven public day care centers of São Paulo city, Southeast Brazil, which enrolled 366 children between 12 and 36 months of age. The data collection occurred between September and December 2010. Each day care center was evaluated for three non-consecutive days, totaling 42 days and 210 meals. Dietary intake was assessed by a direct food weighing method. For the nutritional calculation, DietWin ${ }^{\circledR}$ Profissional 2.0 was used, and the adequacy was calculated according to the recommendations of the National School Feeding Program for energy, protein, calcium and sodium. The calcium/protein relation was also calculated, as well as calcium density (mg/1,000kcal).

Results: The energy (406.4kcal), protein $(18.2 \mathrm{~g})$ and calcium (207.6mg) consumption did not reach the recommended values in all the evaluated day care centers. Sodium intake exceeded up to three times the recommendation. The calcium/protein ratio of $11.7 \mathrm{mg} / \mathrm{g}$ was less than the adequate one $(20 \mathrm{mg} / \mathrm{g})$.

Conclusions: There was inadequacy of calcium, protein and sodium dietary intake, in children attending public day-care centers.

Key-words: child; osteoporosis; calcium, dietary; sodium, dietary; child day care centers; school health.

\section{RESUMO}

Objetivo: Avaliar a ingestão de cálcio, proteína e sódio e compará-la com a recomendada, em crianças que frequentam creches públicas.

Métodos: Estudo transversal descritivo realizado em berçários de sete creches públicas do município de São Paulo, que atendiam 366 crianças entre 12 e 36 meses, com coleta entre setembro a dezembro de 2010. Avaliou-se cada creche durante três dias não consecutivos, totalizando 42 dias e 210 refeições. $\mathrm{O}$ consumo alimentar foi avaliado por método de pesagem direta de alimentos. Para o cálculo nutricional, utilizou-se o software DietWin Profissional $2.0^{\circledR}$ e a adequação foi calculada segundo as recomendações do Programa Nacional de Alimentação Escolar (PNAE) para energia, proteína, cálcio e sódio. A relação cálcio/proteína e a densidade de cálcio (mg/1.000kcal) também foram computadas.

Resultados: Constatou-se que o consumo de energia (406,4kcal), de proteína (18,2g) e de cálcio $(207,6 \mathrm{mg})$ não atingiu os valores recomendados em todas as creches estudadas, sendo que a ingestão de sódio ultrapassou em até três vezes a recomendação. A relação cálcio/proteína de $11,7 \mathrm{mg} / \mathrm{g}$ foi inferior à adequação $(20 \mathrm{mg} / \mathrm{g})$.

Conclusões: Há inadequação do consumo alimentar de cálcio, proteína e sódio, em crianças inseridas no contexto de creches públicas.

Palavras-chave: criança; osteoporose; cálcio na dieta; sódio na dieta; creches; saúde escolar.
Instituição: Universidade Federal de São Paulo (Unifesp), São Paulo, SP, Brasil

${ }^{1}$ Faculdade de Nutrição da Universidade Federal de Alagoas (UFAL), Maceió, AL, Brasil

2Escola Paulista de Medicina da Unifesp, São Paulo, SP, Brasil

${ }^{3}$ Universidade Federal de Pernambuco (UFPE), Recife, PE, Brasil

\author{
Endereço para correspondência: \\ Giovana Longo-Silva \\ Avenida Lourival Melo Mota, s/n - Tabuleiro dos Martins \\ CEP 57072-900 - Maceió/AL \\ E-mail: giovana_longo@yahoo.com.br
}

Conflito de interesse: nada a declarar

Recebido em: 19/9/2013

Aprovado em: 25/11/2013 


\section{RESUMEN}

Objetivo: Evaluar la ingestión de calcio, proteína y sodio y compararla con la recomendada.

Métodos: Estudio transversal descriptivo realizado en nidos de siete guarderías públicas del municipio de São Paulo, que atendían a 366 niños entre 12 y 36 meses, siendo el periodo de recolección de septiembre a diciembre de 2010. Se evaluó cada guardería durante tres días no consecutivos, totalizando 42 días y 210 comidas. El consumo alimentar fue evaluado por método de pesaje directa de alimentos. Para el cálculo nutricional, se utilizó el software DietWin Profissional $2.0^{\circledR}$ y la adecuación se calculó según las recomendaciones del Programa Nacional de Alimentación Escolar (PNAE) para energía, proteína, calcio y sodio. La relación calcio/proteína y la densidad de calcio $(\mathrm{mg} / 1.000 \mathrm{kcal})$ también fueron computados.

Resultados: Se constató que el consumo de energía (406,4kcal), de proteína $(18,2 \mathrm{~g})$ y de calcio $(207,6 \mathrm{mg})$ no alcanzó los valores recomendados en todas las guarderías estudiadas, siendo que la ingestión de sodio sobrepasó en hasta tres veces la recomendación. La relación calcio/proteína de $11,7 \mathrm{mg} / \mathrm{g}$ fue inferior a la adecuada $(20 \mathrm{mg} / \mathrm{g})$.

Conclusiones: Los resultados de este estudio señalan la inadecuación del consumo alimentar de calcio, proteína y sodio, suministrando subsidios para el conocimiento sobre la ingestión de los nutrientes en la población infantil y para el primer paso de toma de conciencia y evaluación del consumo alimentar de niños insertados en el contexto de guarderías públicas.

Palabras clave: niño; osteoporosis; calcio en la dieta; sodio en la dieta; guarderías; salud escolar.

\section{Introduction}

In the last century, life expectancy has increased considerably in both developed and developing countries, which has favored a notable increase in the incidence of age-related diseases, among them osteoporosis ${ }^{(1)}$. The risk of osteoporotic fractures throughout life reaches $40 \%$ among women and $13 \%$ among men $^{(2)}$. Maintaining bone health is, therefore, one of the major challenges of modern Medicine.

Once the disease is established, it is very difficult to reverse it. Despite all health care strategies, the prevention actions should be prioritized, emphasizing the importance of bone mineralization in the early stages of life, since the acquisition of bone mass occurs mainly in the childhood, and the realization of this peak depends on multiple factors, being nutrition one of the most important ${ }^{(3,4)}$.

Although many nutrients are involved in maintaining bone health, calcium is especially important during periods of rapid growth such as infancy and adolescence ${ }^{(5-7)}$, with its fundamental contribution in the prevention of various diseases in later life, such as obesity, hypertension, insulin resistance, kidney stones, and colon cancer ${ }^{(6,7)}$. On the other hand, the reduced intake causes the mineral already used in the bone to be relocated to other vital physiological functions, such as maintenance of calcium levels ${ }^{(8)}$.

Despite the importance to achieve adequate calcium intake for public health, numerous studies indicate that calcium intake and the consumption of dairy products, main sources of this mineral ${ }^{(6)}$, are frequently lower to the recommended for children, especially in the context of public daycare centers ${ }^{(9-11)}$. However, to assess calcium intake, one must consider the influence of other nutrients that act on its absorption and utilization. In this sense, its sufficient intake is added to the adequate consumption of sodium and the calcium-protein ratio, being established as convenient in the proportion of $<20 \mathrm{mg} / \mathrm{g}^{(12,13)}$.

In this context, the aim of this study was to assess the intake of protein, calcium, and sodium, and to compare it to the recommended daily intake, considering it important to promote future nutritional improvements in the school environment.

\section{Method}

This study is part of the "Projeto CrechEficiente - ("Efficient Daycare" Project) Impact of training educators in public/ philanthropic daycare centers on hygiene and dietary practices and on infant health and nutrition, whose objectives were to capacitate, improve, and update the daycare educators regarding health care an nutrition provided to infants, as well as to evaluate the educators' acquisition of knowledge related to the activities performed. The selection process of daycare centers and the adopted criteria are described in another publication $^{(14)}$. Of the eight selected daycare centers, one was excluded because it presented no interest in participating in the survey in the period of data collection.

The present study is a cross-sectional, descriptive study developed in the 14 nurseries in the seven selected nurseries. Data collection took place from September to December 2010 and was conducted by four post-graduate researchers from Universidade Federal de São Paulo (Unifesp). 
To assess dietary intake, we used the direct weighing of food to ensure the precision and accuracy of the results, considering the average intake of the group. This methodology has been used repeatedly in Brazilian nurseries, thus, constituting an instrument for this purpose $\mathrm{e}^{(10,15,16)}$.

All institutions worked full time, from Monday to Friday, and we evaluated all catered meals (breakfast, morning snack or hydration, lunch, afternoon snack, and dinner), during three non-consecutive days, totaling 42 days of analysis and 210 meals.

The weighing of solid foods was performed with a Plenna ${ }^{\circledR}$ portable digital scale with capacity of $5 \mathrm{~kg}$. Liquid foods were measured with the aid of a graduated container (plastic cup) every $50 \mathrm{~mL}$ and with a capacity of $1000 \mathrm{~mL}$.

We weighed three portions of food and/or preparation, randomly selected, to obtain the average number served. We collected uneaten food in plastic bags, considering as discarded any food left in the cup or plate. Also, to obtain the weight of the rejected meal, weights were collected individually for each food and/or preparation, served for breakfast, morning snack, afternoon snack, and dinner, when composed solely of soup. However, at lunch and dinner, meals in which food is served on the plate and mixed, the analysis examined the proportional waste for each food and/or preparation.

Obtaining the mean of food and/or preparations served, we multiplied the value by the number of children in each group. The repetitions were added to the total value, obtaining, thus, the total weight of each food and/or preparation. From this value we subtracted the waste of each food served and, finally, divided by the number of children in each group, obtaining then, the per capita amount of each food and/or preparation. To calculate the nutritional value of the meals, we used the DietWin Profissional 2.0 ${ }^{\circledR}$ software.

We calculated the percentage of recommendation for calcium, protein, and sodium, considering the reference values set for the National School Meal Program - 70\% of the daily nutritional needs ${ }^{(17)}$.

Due to the absence of standard recipes for preparing soups, milk, and juices, the team followed the preparation, previously weighing all ingredients used and the final yield. The nutritional information of each preparation was also calculated in DietWin Profissional $2.0^{\circledR}$ and, afterwards, inserted as a new preparation on the food list.

To determine the socioeconomic profile of children attending the institutions analyzed, we applied a questionnaire to parents to identify the family income of each child, obtained through information on wages and other sources of income of all members of the family unit. The sum obtained was expressed in Brazilian Reais and converted in units of the minimum wage $(\mathrm{MW})$ in effect during the study period. We described the simple frequencies and percentages of the distribution per age, gender, and economic class of the children.

All data obtained were double entered, validated and analyzed using the Epi-Info 2000 statistical software, version 3.4.3. The project was approved by the Research Ethics Committee of Unifesp (n. 0442/10).

\section{Results}

The socioeconomic characteristics of the children enrolled in the daycare centers analyzed are included in Table 1, and it was noteworthy that the gender distribution of children

Table 1 - Demographic and socioeconomic characteristics of children attending public daycare centers. São Paulo, SP, 2010

\begin{tabular}{|c|c|c|c|c|c|c|c|c|}
\hline & \multicolumn{8}{|c|}{ Daycare Centers } \\
\hline & 1 & 2 & 3 & 4 & 5 & 6 & 7 & Total \\
\hline & n (\%) & n (\%) & n (\%) & $\mathrm{n}(\%)$ & n (\%) & n (\%) & n (\%) & n (\%) \\
\hline \multicolumn{9}{|c|}{ Age (months) } \\
\hline 12 to 24 & $38(49.4)$ & $24(54.5)$ & $30(50.8)$ & $28(43.1)$ & $7(31.8)$ & $25(46.3)$ & $8(17.8)$ & $160(43.7)$ \\
\hline 24 to 36 & $39(50.6)$ & $20(45.5)$ & $29(49.2)$ & 37 (56.9) & $15(68.2)$ & $29(53.7)$ & $37(82.2)$ & $206(56.3)$ \\
\hline \multicolumn{9}{|l|}{ Sex } \\
\hline Female & $35(45.5)$ & $20(45.5)$ & $23(39.0)$ & $24(36.9)$ & $10(45.5)$ & $22(40.7)$ & $21(46.7)$ & $155(42.3)$ \\
\hline Male & $42(54.5)$ & $24(54.5)$ & $36(61.0)$ & $41(63.1)$ & $12(54.5)$ & $32(59.3)$ & $24(53.3)$ & $211(57.7)$ \\
\hline \multicolumn{9}{|c|}{ Family Income (MW)* } \\
\hline$<1$ & $1(1.3)$ & $6(13.6)$ & $7(12.1)$ & $5(7.8)$ & $1(4.5)$ & $2(3.8)$ & $3(6.7)$ & $25(6.9)$ \\
\hline $1+2$ & $23(29.9)$ & $26(59.1)$ & $19(32.8)$ & $21(32.8)$ & $7(31.8)$ & $21(39.6)$ & $19(42.2)$ & $136(37.5)$ \\
\hline $2+3$ & $26(33.8)$ & $5(11.4)$ & $18(31.0)$ & $18(28.1)$ & $2(9.1)$ & $10(18.9)$ & $13(28.9)$ & $92(25.3)$ \\
\hline$>3$ & $27(35.1)$ & $7(15.9)$ & $14(24.1)$ & $20(31.3)$ & $12(54.5)$ & $20(37.7)$ & $10(22.2)$ & $110(30.3)$ \\
\hline
\end{tabular}

*Minimum wage during the study period, corresponding to 510.00 Brazilian Reais 
Table 2 - Consumption of energy, calcium, protein, sodium, calcium/protein ratio, calcium density in the diet of children attending public daycare centers. São Paulo, SP, 2010

\begin{tabular}{|c|c|c|c|c|c|c|c|c|}
\hline Daycare & 1 & 2 & 3 & 4 & 5 & 6 & 7 & Median \\
\hline \multicolumn{9}{|l|}{ Energy (kcal) } \\
\hline Median & 436.7 & 380.1 & 559.2 & 497.6 & 514.1 & 455.8 & 536.6 & 406.4 \\
\hline $1^{\text {st }}$ quartile* & 402.6 & 309.4 & 436.8 & 398.6 & 447.3 & 394.2 & 457.7 & 402.6 \\
\hline $4^{\text {th }}$ quartile* & 471.7 & 460.4 & 648.3 & 605.8 & 578.5 & 579.4 & 578.4 & 572.6 \\
\hline \multicolumn{9}{|l|}{ Calcium (mg) } \\
\hline Median & 216.5 & 162.2 & 205.3 & 230.4 & 153.3 & 198.8 & 281.6 & 207.6 \\
\hline $1^{\text {st }}$ quartile* & 188.8 & 91.9 & 167.6 & 193.8 & 138.6 & 148.9 & 227.3 & 167.4 \\
\hline $4^{\text {th }}$ quartile ${ }^{*}$ & 285.1 & 215.4 & 227.4 & 274.3 & 167.5 & 258.2 & 334.5 & 268.0 \\
\hline \multicolumn{9}{|l|}{ Protein (g) } \\
\hline Median & 15.0 & 13.1 & 22.6 & 19.9 & 14.1 & 18.6 & 21.3 & 18.2 \\
\hline $1^{\text {st }}$ quartile* & 13.9 & 10.0 & 17.5 & 15.7 & 11.1 & 17.2 & 20.6 & 14.3 \\
\hline $4^{\text {th }}$ quartile* & 17.9 & 16.0 & 29.6 & 24.9 & 15.4 & 19.7 & 27.4 & 21.4 \\
\hline \multicolumn{9}{|l|}{ Sodium (mg) } \\
\hline Median & 395.5 & 224.8 & 292.7 & 451.8 & 495.9 & 597.1 & 501.2 & 413.4 \\
\hline $1^{\text {st }}$ quartile* & 291.8 & 171.8 & 208.7 & 213.8 & 426.6 & 164.1 & 383.3 & 219.6 \\
\hline $4^{\text {th }}$ quartile* & 617.4 & 265.0 & 514.0 & 633.4 & 614.2 & 716.2 & 625.5 & 615.0 \\
\hline \multicolumn{9}{|c|}{ Calcium/protein (mg/g) } \\
\hline Median & 13.8 & 12.0 & 9.5 & 12.0 & 11.8 & 10.3 & 11.5 & 11.7 \\
\hline $1^{\text {st }}$ quartile* & 11.6 & 8.4 & 7.6 & 10.7 & 10.2 & 8.5 & 10.3 & 10.0 \\
\hline $4^{\text {th }}$ quartile* & 18.0 & 14.0 & 11.3 & 13.7 & 1.7 & 13.7 & 15.2 & 14.3 \\
\hline \multicolumn{9}{|c|}{ Calcium density (mg/1,000kcal) } \\
\hline Median & 541.7 & 413.7 & 406.8 & 512.4 & 318.4 & 415.5 & 545.8 & 450.6 \\
\hline $1^{\text {st }}$ quartile* & 346.4 & 212.2 & 334.5 & 462.7 & 283.9 & 321.7 & 452.1 & 327.1 \\
\hline $4^{\text {th }}$ quartile* & 691.2 & 562.4 & 435.3 & 536.1 & 344.5 & 481.9 & 621.2 & 547.1 \\
\hline
\end{tabular}

*The median intake of each nutrient was divided into quartiles containing, in each daycare center, two nurseries evaluated during 3 days (15 meals)

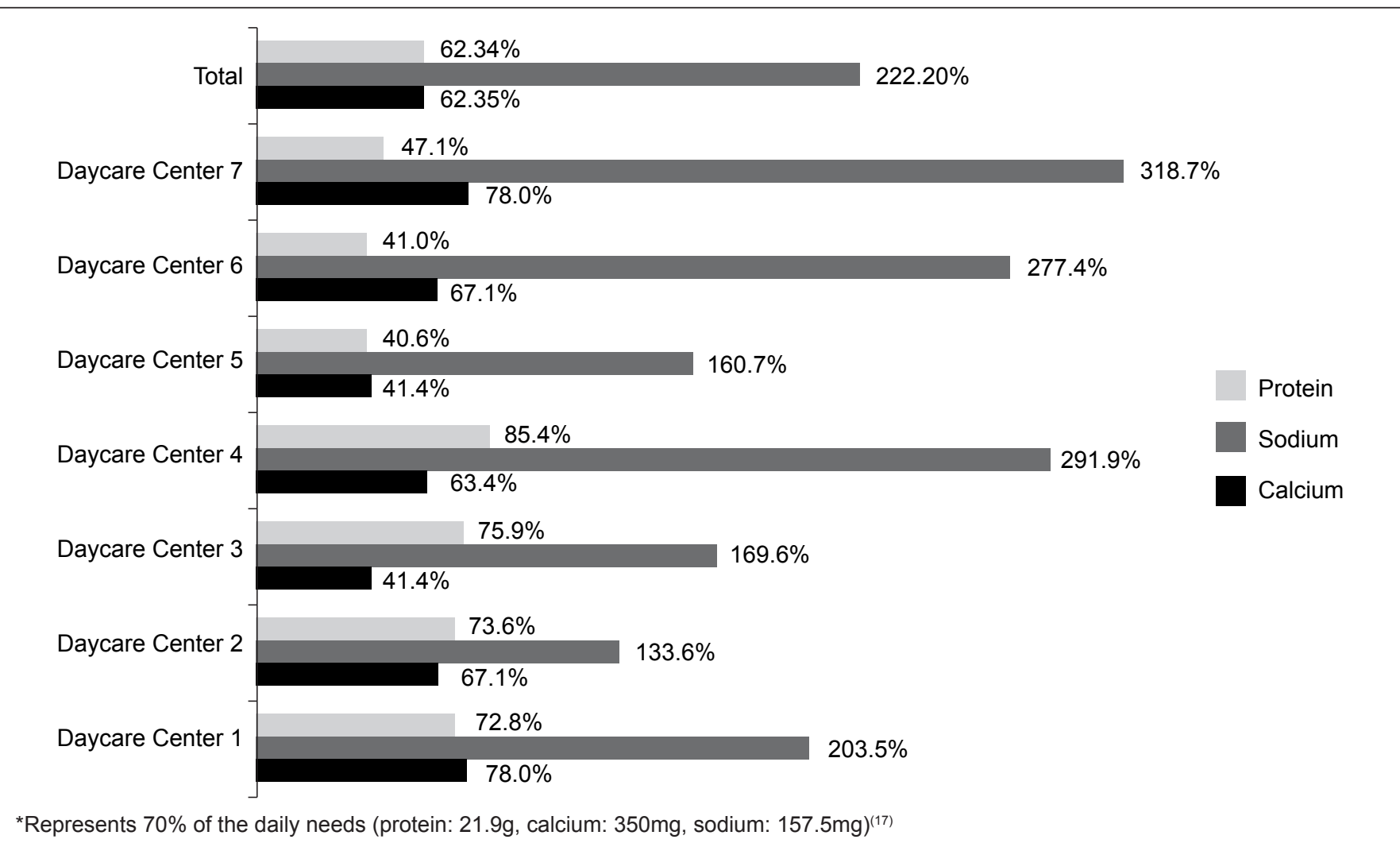

Figure 1 - Percentage of recommended* intake of protein, calcium, and sodium in public daycare centers. São Paulo, SP, 2010 
attending the seven daycare centers was homogeneous, with 366 children aged between 12 and 36 months. The economic conditions of the families involved indicate that $62.8 \%$ present a family income ranging between one and three minimum wages.

The food intake based on median values and values corresponding to the first and fourth quartiles on the distribution of energy, calcium, protein, sodium, as well as the calcium/ protein ratio and the density of calcium $(\mathrm{mg} / 1000 \mathrm{kcal})$, are expressed in Table 2, which shows equivalent values among the different nurseries, representing uniformity regarding food in public institutions.

Figure 1 shows the percentage of recommended intake of protein, sodium, and calcium, demonstrating that the mean consumption of calcium and protein is below the values stipulated by PNAE; on the other hand, there was variation from 133.6 to $318.7 \%$ in the percentage of sodium adequacy.

\section{Discussion}

The results showed that the average energy consumption was $406.4 \mathrm{kcal}$, a much lower value than the expected $(700 \mathrm{kcal})^{(17)}$. Similar results were found by Spinelli et a $l^{(16)}$ and by Menezes and Osório ${ }^{(18)}$, who obtained, respectively, energy adequacy of 57 and $41 \%$. Therefore, the feeding at home in the evening and in the morning is essential to complete the nutritional needs and should be guided by nutritionists, harmonizing the actions of educators in childcare centers and of parents at home.

Under this approach, the percentage of protein adequacy $(62.3 \%)$ can therefore, be conditional on, the low energy consumption and, consequently, to macronutrients in general, with a contribution in total energy intake of $12.3 \%$.

It is noteworthy that the compliance with the recommended percentage of protein contributes to growth, bone maintenance, and prevention of osteoporosis while its deficiency or excess can be deleterious. Morais and Burgos ${ }^{(8)}$ warn that adding $50 \mathrm{~g}$ of protein in the diet increases approximately $1.6 \mathrm{mmol}$ in the excretion of calcium, which is considered a regulator of urinary calcium excretion, more important than the actual intake of the mineral.

In parallel, the results presented here revealed percentages of adequate intake of calcium between 41.4 and $78 \%$ in daycare centers, so the low consumption by children was generalized. Similar data was identified in a study conducted by Spinelli et $a^{(16)}$ in public daycare centers in São Paulo, whose adequacy of calcium intake by children between 12 and 18 months, adjusted to $70 \%$ of needs, was of $51.7 \%$. This percentage, lower than the recommendation, may be linked to the supply of dairy products, as, although the menu offered in these institutions provides two servings of milk (breakfast and afternoon snack), the per capita amount is insufficient, further adding the high amount of wastage, which represents an index of waste-consumption of around $50 \%{ }^{(19)}$. On the same premise in Aracaju, SE, Oliveira et $a l^{(20)}$ found that, of 359 children from 6 to 35 months of age analyzed, $47.7 \%$ presented consumption of milk and dairy products lower than the three servings recommended for this population.

As mentioned earlier, there is strong evidence of reduced consumption of calcium in all stages of life, cultures and regions, both in developed and in developing countries. Corroborating this assertion, Rajeshwari et al ${ }^{(21)}$ followed children from 10 years to adulthood, demonstrating that calcium intake is reduced during this period, with considerable reduction from childhood ( $54 \%$ below the recommended level) to adulthood (77\% below the recommendation). Similarly, Salamoun et al ${ }^{(22)}$, analyzing children from the Mediterranean, found that only $12 \%$ reached the recommendation for this mineral. Also, the Bogalusa Heart Study ${ }^{(23)}$ found that $69 \%$ of children did not meet the recommended intake. In the Spanish population, the amount of individuals with ingestion of calcium below the recommended levels was also found to be high, with a prevalence of $22 \%$ in preschool children ${ }^{(24)}$.

These findings are of concern due to the losses caused by the insufficient intake of calcium in childhood for the definition of the peak bone mass, considering this insufficient intake critical for the occurrence of osteoporosis in adulthood. Thus, children attending public daycare centers would be susceptible to reduced peaks of bone mass and greater risk of osteoporosis and early factures in adult life ${ }^{(25)}$. Besides the insufficient intake of calcium, the calcium-protein ratio was also inadequate: the median of this ratio in this study was of $11.8 \mathrm{mg} / \mathrm{g}$, below the $<20 \mathrm{mg} / \mathrm{g}$, established as appropriate ${ }^{(12,13)}$.

In this premise, Moreira et al ${ }^{(26)}$ emphasize the importance of calcium intake in relation to proteins, consigning the importance of this proportion, especially to eliminate errors in the estimates of intake. These authors found a ratio of $11.1 \pm 3.7$ and $11.0 \pm 3.8 \mathrm{~g}$ between Portuguese boys and girls, respectively. Similar data was found by Ortega et $a l^{(9)}$, whose proportion of nutrients was of $10.1 \pm 2.8 \mathrm{~g}$ in a representative sample of children. 
As for sodium intake in the present study, the percentage reached from 133.6 to $318.7 \%$ of the recommended between the assessed daycare centers. This findings is disturbing, since children acquire a taste for salt according to the amount they consume daily ${ }^{(27)}$.

The mentioned percentages, if kept frequent or rising in the diet of these children, can cause negative health impacts in the short- and long-term, once high sodium intake is known to be associated with increased prevalence of hypertension, acute myocardial infarction, renal failure, and stroke ${ }^{(28)}$. Furthermore, excess sodium is also related to the reduction of peak bone mass in adolescence and with the acceleration of bone loss input throughout life ${ }^{(24,29)}$.

According to Pan et al ${ }^{(30)}$, sodium is among the major determinants of calcium excretion and it is estimated that a diet increased with $100 \mathrm{mmol}$ of sodium produces $1 \mathrm{mmol}$ in urinary excretion of calcium ${ }^{(31)}$.

Besides its importance in the promotion of bone health, the early, excessive, and continued intake of a diet high in sodium contributes to increased blood pressure levels, which is considered the best predictor of blood pressure levels in adulthood. It is noteworthy that the clinical manifestation may already occur in childhood, with the prevalence of hypertension observed in Brazilian children and adolescents from 2.3 to $31 \%$, reaching $51.7 \%$.

Despite the findings reported here, we should also mention the restrictions stipulated by PNAE on Resolution/CD/FNDE n. 38, of July, 2009 $9^{(17)}$ in the use of sausages, sweets, pre-ready meals (or ready) or processed foods (in powder or dehydrated for reconstitution), with high amount of sodium (those with an amount equal or greater than $500 \mathrm{mg}$ per $100 \mathrm{~g}$ or $\mathrm{mL}$ ).

It should also be emphasized that food supplementation is provided within the family context, which, according o the guidelines of the PNAE, should provide the intake of $30 \%$ of the daily nutritional needs. Although this study has not

\section{References}

1. Bonura F. Prevention, screening, and management of osteoporosis: an overview of the current strategies. Postgrad Med 2009;121:5-17.

2. LaFleur J, McAdam-Marx C, Kirkness C, Brixner DI. Clinical risk factors for fracture in postmenopausal osteoporotic women: a review of the recent literature. Ann Pharmacother 2008;42:375-86.

3. Martínez MJ, Redondo D, Conde F, Redondo P, Alonso Franch M. Gráficas longitudinales de velocidad de conducción media de ultrasonidos en falanges. Estudio nutricional de Castilla y León. Valladolid: Junta Castilla y León; 2009.

4. Gimeno Ballester J, Azcona San Julián C, Sierrasesúmaga Ariznabarreta L. Bone mineral density determination by osteosonography in healthy children and adolescents: normal values. An Esp Pediatr 2001;54:540-6. investigated household consumption, Toloni et al ${ }^{(33)}$ analyzed the introduction of processed foods in these very institutions and found that approximately two thirds of children were offered by the parents, in the home environment, instant noodles, snacks, sandwich cookies, sausages, artificial juice, soda, candy, and lollipop before 12 months of age. These data indicate the probability that the nutritional complementing, within the family context, does not contribute positively to the total adequate daily nutritional intake, emphasizing the possible availability of foods high in sodium.

Despite the inherent limitations of studies with nonprobabilistic sampling procedures and biases related to different methods of dietary surveys, such as incorrect recording of answers, coding error, conversion of food into nutrients, decalibrated instruments, and inter and intrapersonal variation, it is noteworthy that the studied institutions have socioeconomic and demographic characteristics similar to the universe of public daycare centers in the municipality of São Paulo, reflecting the reality of municipal institutions. Furthermore, to minimize measurement bias, there was a training of the team, collection on non-consecutive days, calibration of equipment, as well as review and evaluation of the consistency of the instruments and the data.

Therefore, the results of this study, which reflected the inadequacy of dietary intake of calcium, protein, and sodium, are considered a first step towards awareness regarding the recommended intake for the pediatric population, especially within the context of public daycare centers.

The action strategies in the prevention of chronic diseases related to nutrition, such as osteoporosis and hypertension, are not restricted to the medical scope and need interventions in the field of Public Health in daycare centers and schools, in the media, and other spaces where civil society lives. Thus, it is expected that the results of this study may help promote efforts that contribute to a better bone health future.

5. Suárez Cortina L, Moreno Villares JM, Martínez V, Aranceta J, Dalmau J, Gil A et al. Ingesta de cálcio y densidad mineral ósea en una población de escolares españoles (estudio CADO). An Pediatr (Barc) 2011;34:3-9.

6. Vue H, Reicks M. Individual and environmental influences on intake of calciumrich food and beverages by young Hmong adolescent girls. J Nutr Educ Behav 2007;39:264-72.

7. Larson NI, Neumark-Sztainer D, Harnack L, Wall M, Story M, Eisenberg ME. Calcium and dairy intake: longitudinal trends during the transition to young adulthood and correlates of calcium intake. J Nutr Educ Behav 2009;41:254-60.

8. Morais GQ, Burgos MG. Nutrients impact on bone health: new trends. Rev Bras Ortop 2007;42:189-94. 
9. Ortega RM, López-Sobaler AM, Jiménez Ortega Al, Navia Lombán B, RuizRoso Calvo de Mora B, Rodríguez-Rodrígues $\mathrm{E}$ et al. Food sources and average intake of calcium in a representative sample of Spanish schoolchildren. Nutr Hosp 2012;27:715-23.

10. Longo-Silva G, Toloni MH, Goulart RM, Taddei JA. Evaluation of food consumption at public day care centers in São Paulo, Brazil. Rev Paul Pediatr 2012;30:35-41.

11. Serra-Majem L, Ribas-Barba L, Salvador G, Jover L, Raidó B, Ngo J et al. Trends in energy and nutrient intake and risk of inadequate intakes in Catalonia, Spain (1992-2003). Public Health Nutr 2007;10:1354-67.

12. Ortega RM, López-Sobaler AM, Requejo RM, Andrés P. La composición de los alimentos. Herramienta básica para la valoración nutricional. Objetivos nutricionales marcados para la población española. Departamento de Nutrición. Madrid: Complutense; 2010. p. 86.

13. Weinsier RL, Krumdieck CL. Dairy foods and bone health: examination of the evidence. Am J Clin Nutr 2000;72:681-9.

14. Konstantyner T, Taddei JA, Oliveira MN, Palma D, Colugnati FA. Isolated and combined risks for anemia in children attending the nurseries of daycare centers. J Pediatr (Rio J) 2009;85:209-16.

15. Alves G, Colauto EV, Fernandes JK, Zabine L, Nienow RC. Anthropometric and food intake assessment of preschoolers in day-care centers in Umuarama, Paraná. Arq Ciências Saúde Unipar 2008;12:119-26.

16. Spinelli MG, Goulart RM, Santos AL, Gumiero LD, Farhud CC, Freitas EB et al. Six to eighteen-month-old children's food intake in day-care centers. Rev Nutr 2003;16:409-14.

17. Brasil - Ministério da Educação. Fundo Nacional de Desenvolvimento da Educação. Conselho Deliberativo [homepage on the Internet]. Resolução/ CD/FNDE $n^{\circ} 38$, de 16 de julho de 2009. Dispõe sobre o atendimento da alimentação escolar aos alunos da educação básica no Programa Nacional de Alimentação Escolar - PNAE [cited 2014 Mar 9]. Available from: http://www. asbran.org.br/sitenovo/arquivos/resolucao38.pdf

18. Menezes RC, Osório MM. Energy and protein intake and nutritional status of children under five years of age in Pernambuco state, Brazil. Rev Nutr 2007;20:337-47.

19. Longo-Silva G, Toloni MH, Rocha AM, Rodrigues S, Taddei JA. Evaluation of the menu, food consumption and food waste in outsourced public daycare centers in Brazil. Nutrícias 2012;14:10-5.
20. Oliveira S Filha E, Araújo JS, Barbosa JS, Gaujac DP, Santos CF, Silva DG Consumption of food groups among children attending the public health system of Aracaju, Northeast Brazil, in Sergipe. Rev Paul Pediatr 2012;30:529-36.

21. Rajeshwari R, Nicklas TA, Yang SJ, Berenson GS. Longitudinal changes in intake and food sources of calcium from childhood to young adulthood: the Bogalusa Heart Study. J Am Coll Nutr 2004;23:341-50.

22. Salamoun MM, Kizirian AS, Tannous RI, Nabulsi MM, Choucair MK, Deeb ME et al. Low calcium and vitamin $\mathrm{D}$ intake in healthy children and adolescents and their correlates. Eur J Clin Nutr 2005;59:177-84.

23. Nicklas TA. Calcium intake trends and health consequences from childhood through adulthood. JACN 2003;22:340-56.

24. Ortega RM, Requejo AM, Navia B, Quintas ME, Andrés P, López-Sobaler $\mathrm{M}$ et al. The consumption of milk products in a group of pre-school children: influence on serum lipid profile. Nutr Res 2000;20:779-90.

25. Tucker KL. Does milk intake in childhood protect against later osteoporosis? Am J Clin Nutr 2003;77:10-1.

26. Moreira P, Padez C, Mourão I, Rosado V. Dietary calcium and body mass index in Portuguese children. Eur J Clin Nutr 2005;59:861-7.

27. Ramos M, Stein LM. Desenvolvimento do comportamento alimentar infantil. J Pediatr (Rio J) 2000;76:229-37.

28. Costa FP, Machado SH. Does the consumption of salt and food rich in sodium influence in the blood pressure of the infants? Cien Saude Colet 2010;15 (Suppl 1):1383-9.

29. Cappuccio FP, Kalaitzidis R, Duneclift S, Eastwood JB. Unravelling the links between calcium excretion, salt intake, hypertension, kidney stones and bone metabolismo. J Nephrol 2000;13:169-77.

30. Pan W, Borovac J, Spicer Z, Hoenderop JG, Bindels RJ, Shull GE et al. The epithelial sodium/proton exchanger, NHE3, is necessary for renal and intestinal calcium (re)absorption. Am J Physiol Renal Physiol 2012;302:F943-56.

31. Cirillo M, Ciacci C, Laurénzi M, Mellone M, Mazzacca G, De Danto NG. Salt intake, urinary sodium, and hypercalciuria. Miner Eletrolyte Metab 1997;23:265-8.

32. Bezerra ML, Soares PF, Leite ES, Lucena RC. Hypertension in children and adolescents: a systematic review about prevalence and risk factors. Rev Enferm UFPE 2013;7:5313-22.

33. Toloni MH, Longo-Silva G, Goulart RM, Taddei JA. Introduction of processed and traditional foods to the diets of children attending public daycare centers in São Paulo, Brazil. Rev Nutr 2011;24:61-70. 